\title{
24 Hour Urine for Total Protein
}

National Cancer Institute

\section{Source}

National Cancer Institute. 24 Hour Urine for Total Protein. NCI Thesaurus. Code C135567.

The measurement of the total protein present in a urine sample that was collected over a period of 24 hours. 